\title{
32 \\ THE “WAR ON SMUGGLERS” AND THE EXPANSION OF THE BORDER APPARATUS
}

\author{
Lorena Gazzotti
}

\section{Introduction}

The website of the EU Directorate for Migration and Home Affairs includes a page dedicated to "migrant smuggling." It states that "migrant smuggling is a profitable business for criminal networks with estimated annual turnover reaching multiple billion Euros." It then goes on detailing that "Migrant smuggling is increasingly associated with serious human rights violations and deaths, in particular when it occurs by sea." The website continues by arguing that "The loss of migrants' lives at the hands of smugglers in the Mediterranean Sea is an acute reminder of the need to tackle migrant smuggling," an endeavor that justifies resorting to "all of the legal, operational, and administrative levers available" (European Commission, n.d.). Similar in both forms and content to speeches recited by both right-wing and left-wing European political leaders, this short extract exemplifies the role that the "smuggler" plays in current political discourses. Together with the archetypical figure of the "terrorist" (De Genova, 2010), the "homeless," or "the drug trafficker" (De Noronha, 2020), the "smuggler" quintessentially condenses the anxieties of late liberal societies: they are stigmatised as deviant because they do not conform to the established order, and they are therefore portrayed as a source of threat that conspires against the status quo.

Literature has now widely acknowledged that the public portrait of the smuggler as an inherently deviant, dangerous figure is deceiving. In this chapter, however, I will not focus on the mismatch between the realities and political fantasies about the "smuggler." Rather, this paper interrogates the "uses"1 of smuggling. I ask: what political function does the figure of the "smuggler" fulfill in border control? I contend that the demonization of the smuggler enables the expansion of the border apparatus. Casting the "smuggler" as the main source of danger for people crossing the border irregularly (and for destination countries enacting restrictive migration policies) displaces attention away from the structural sources that create a demand for human smuggling in the first place. Individualizing and pathologizing the dangers connected to smuggling facilitate the deployment of further border control measures. Following Rob Nixon's concept of "slow violence" (Nixon, 2011), I argue that anti-smuggling activities can be categorized into fast control instruments, that deploy military-style interventions focusing on destroying the infrastructures that facilitate irregular border crossing; and slow control methods, that aim at transforming potential migrants and former smugglers into immigration-law-abiding 
subjects through welfare-like initiatives. Although they might not appear to be successful in their intent to disrupt smuggling networks and economies, these projects do succeed in advancing the border project: they further precarise the life conditions of migrant people, and they reinforce the idea that migration is a "problem" that can be "solved" through ad-hoc, time-bounded, rapid interventions.

The rest of the chapter unfolds into four sections. The first section explores the existing academic literature on smuggling, providing a more nuanced and complex understanding of the facilitation of irregular migration. The following section provides a framework to conceptualise the expansion and diversification of the bordering apparatus. I then move on to discussing the difference between "fast" and "slow" anti-smuggling instruments of smuggling control, and how they contribute (explicitly and implicitly) to the expansion of the border apparatus.

\section{“Dangerous smugglers" vs. "moral smugglers"?}

In both policy literature and journalistic prose, people smugglers are generally described as "inherently hypersexual and violence-driven men from the global South, members of allmighty, hierarchical, transnational criminal organisations, involved in markets ranging from weapons trafficking to terrorism and from drug trafficking to nuclear smuggling" (Sanchez, 2016, p. 390). In its 'Migrant Smuggling FAQs', for example, UNODC specifies that "Migrant smugglers are criminals and not humanitarians. They are motivated by financial or material gain" (UNODC, n.d.). The report continues by specifying that "migrant smugglers often conduct their activities with little or no regard for the lives of the people whose hardships have created a demand for smuggling services." The International Organization for Migration (IOM) shares such universal views about the indifference of smugglers to their clients: in its 'IOM's comprehensive approach to counter migrant smuggling' report, the organisation describes migrant smugglers are predatory figures, asserting, 'once paid, smugglers often have little or no regard for the well-being of migrants, who are particularly vulnerable to abuse and exploitation' (IOM, n.d.).

Academic research, however, has proven that reality is much more complex (Stock, 2019). First of all, the relations between smugglers and migrants can fall on a wide spectrum between mutual trust and overt violence. Trust and ethical commitment can be essential to the relation between smugglers and migrants, as the former can be seen as care providers who help the latter fleeing a situation of unease and danger when wealthy countries have closed most legal channels for escape (Achilli, 2018; Vogt, 2016). Second, smuggling is not necessarily a secret practice occurring away from the prying eyes of the public. Rather, it can be a mundane activity that is deeply embedded in the local political economy of border regions (Vives, 2017). The demand and supply for smuggling should be understood in the broader context of increasingly securitized borders that generate a source of precarious income for people available to facilitate the crossing of labourers across the border (Sanchez, 2016). Regions that have become central hubs of irregular border crossing have seen the emergence of a parallel service economy that caters to potential border crossers and smugglers, composed of activities as unnewsworthy as "shops, boutiques, restaurants, grocery stores, bus and taxi companies, nightclubs, and pubs" (Achilli, 2018). In this context, the smuggler can be a member of the same community that navigates a complex economic landscape by juggling multiple social positions (Magallanes-Gonzalez, 2020). Third, smuggling is not necessarily a male-dominated economic activity. Building on fieldwork at the US-Mexico border, Sanchez highlights that "smuggling" writ large is undertaken also by women, working either to arrange crossings or to provide a range of services (like maintaining accommodation for potential crossers) that are intimately linked to the 
facilitation of irregular migration (Sanchez, 2016). Fourth, smuggling does not systematically take place far away from the eyes of the authorities. The latter are, in a lot of cases, informed and essential to the everyday working of irregular crossing (Achilli, 2018; Stock, 2019).

The fact that smuggling should not be systematically represented as a hyper-violent activity does not mean that the facilitation of irregular border crossing never relies on threat. Scholars have widely documented that migrants can be victims of sexual violence (Tyszler, 2019), kidnapping (Slack, 2019) and robbery (Magallanes-Gonzalez, 2020) at the hand of smugglers. The level of violence that smuggling implies, however, is intimately linked to the expansion of border securitization policies. In her piece on irregular migration between Senegal and Spain, Luna Vives points out that before 2005, most smuggling was conducted occasionally by Senegalese fishermen, who had the skills to sail the Ocean, and who belonged to the same communities where their clients originated (and that could therefore more easily be held accountable for their wrongdoings). The criminalization of smuggling, however, discouraged this kind of occasional smuggler, paving the way for larger, foreign, criminal organisations to take their place in the facilitation of irregular migration. The change in actor determined an increase in vulnerabilities: migrants were deprived of the accountability systems that provided them with guarantees against deception and threat, and the business of smuggling became the monopoly of people with no experience in sailing in Senegalese waters (Vives, 2017).

\section{"The dangerous smuggler" and the expansion of the border apparatus}

The unwavering attention that political leaders cast on the figure of the "dangerous smuggler" is part of an established pattern of evidence-averse policy-making that characterizes the field of migration. The EU, in fact, tends to adopt policy responses to migration phenomena that are at odds with the existing evidence on the topic. Most important is the perseverance of European governments in adopting ever-more restrictive migration policies to curb immigration, even though scientific evidence exists that prove that tighter borders do not halt existing migration flows. Rather, they oblige migrant people to travel irregularly and to take more dangerous routes (Andersson, 2014). Evidence-averse policy-making happens despite the fact that national governments express a public commitment to evidence-based policy-making, implemented through the funding of research programmes (Baldwin-Edwards et al., 2019). The fact that migration policies are rooted in biased perceptions and racist stereotypes should not be understood as a question of "misinformed" public discourse or policy-making (see also Ferguson, 1994). Rather, it depends on the fact that policy-making is influenced by a number of competing factors, from the bureaucrat's background to the broader political context (BaldwinEdwards et al., 2019). Building on his work on development programs in rural Africa, James Ferguson argued that seemingly 'apolitical' policy reports fulfil a precise political function. By providing a representation of social problems where "politics is conspicuous by its absence" (Ferguson, 1994: 66), these reports prepare the ground for technical intervention, that claim to solve complex social, political and economic issues through the deployment of "highly standardized operations" (Ferguson, 1994: 69).

Although Ferguson writes about a starkly different political field, his observations apply to the analysis of anti-smuggling policies. Casting attention on the figure of the "smuggler" obscures the political conditions that make the service of smugglers necessary in the first place, and that make border areas and migration routes more generally so dangerous for people racialized as "migrant others" (Gross-Wyrtzen, 2019). This enables a massive expansion of the border apparatus (Carling and Hernández-Carretero, 2011). In the past three decades, anti-smuggling activities have proliferated across the North and the South. European countries, the US and 
Australia have adopted laws criminalizing irregular migration and its facilitation. Their partner countries in the Global South followed suit, juggling between externalization pressure and desire to strategize migration as a diplomatic tool (Ben Jémia, 2012; Khrouz, 2016). In aidrecipient countries qualified as countries of "transit" or of "origin," the implementation of antismuggling infrastructure was supported by donors as part of their border externalization efforts (Watkins, 2017). Anti-smuggling interventions can be divided broadly in two categories: military-style interventions implemented by traditional security actors (like the police and the army); and welfare-like interventions, implemented by non-traditional security actors like nongovernmental organisations (NGOs) and international organisations (IOs). ${ }^{2}$ In the aftermath of the 2015 migration "crisis," for example, the EU has funded a plethora of anti-smuggling and anti-trafficking activities through its EU Trust Fund for Africa, including a $€ 42$ million project on "Support to Integrated border and migration management" in Libya, a €44 million project on "Support to the integrated border and migration management" in Morocco, and a $€ 8$ million project supporting "Rapid Economic Impact Action Plan in Agadez" (PAIERA). The first two projects work according to a clear military approach, as they aim at expanding the capacity of the Moroccan and Libyan state apparatus to surveil their land and sea borders. As we will see later in this chapter, the PAIERA project, instead, was based on a softer approach, aiming at dismantling smuggling by providing alternative work opportunities to those facilitating irregular migration movements in Niger.

The proliferation of military/humanitarian responses to smuggling could be conceptualized in terms of a combination between "fast" and "slow" instruments of border control. In a seminal book, Rob Nixon draws a distinction between a form of direct violence that is "immediate in time, explosive and spectacular in space, and as erupting into instant sensational visibility" (Nixon, 2011, p. 2) and "slow violence," “a violence that occurs gradually and out of sight, a violence of delayed destruction that is dispersed across time and space, an attritional violence that is typically not viewed as violence at all" (Nixon, 2011, p. 2). ${ }^{3}$

\section{Fast control}

Fast violence instruments deployed to counter smuggling operate in a deductive fashion, through the destruction of the social and logistical infrastructures enabling smuggling. Scholars have pointed out that border policing focuses on three different types of smuggling infrastructures: infrastructures of waiting, through the destruction of makeshift camps (Tyszler, 2019) or the eviction of residents from temporary accommodation in areas hosting people waiting to cross (Bajalia, 2020); infrastructure of crossing, through the interception, seizing and destruction of vessels used by irregular migrants and their facilitators (Garelli \& Tazzioli, 2018); and infrastructures of community, through the forcible dispersal and relocation of migrants away from the borders, either through arrest and forcible abandonment in areas far away from the border and from urban centres, or through relocation to other reception or detention centres (Gazzotti \& Hagan, 2020; Tazzioli, 2019). Such techniques of destruction and dispersal have become commonplace at the French-UK border, especially in the Calais region (Hagan, 2020), at the French-Italian border, especially in Ventimiglia (OXFAM, 2018), and at the Spanish-Moroccan border, mostly in the Moroccan regions surrounding the Spanish enclaves of Ceuta and Melilla (Gazzotti \& Hagan, 2020). In the latter case, police forces tend to attack migrant camps in the early morning, destroy migrant shelters and set the remainder on fire, then force migrant people on buses that forcefully lead them to areas in the Centre and South of Morocco, in areas far away from the border, and often far away from the main urban centres. Such destruction and dispersal campaigns have continued even after the outbreak of the 
COVID-19 pandemic, leaving migrant people particularly vulnerable to the risk of infection and of destitution (Gross-Wyrtzen, 2020).

Although these military-style initiatives operate through fast violence, political leaders often justify them as humanitarian in nature. In 2016, French president Hollande defined the dismantling of the migrant camp in Calais, which become famous as "The Jungle," as responding to a "humanitarian urgency" generated by migrants spreading false rumours and unduly attracting potential border crossers to the North of France:

Everybody must understand that the Calais Jungle is an impasse for migrants. It is also, I know, an action field for smugglers that let [migrants] believe this illusion that it will be possible to cross the border.

It is also necessary to inform those that think that a life here is possible and that at a certain point this will open. No, it will not open (Hollande, 2016, translation mine).

Similarly, Garelli and Tazzioli highlight that the anti-smuggling purpose of the EU's Operation Sophia was framed as humanitarian. It aims at protecting migrants by preventing them access to unsafe migration routes, and by decreasing the logistical capacity of smugglers to prey on migrants by charging them exorbitant prices for extremely risky journeys (Garelli \& Tazzioli, 2018). In Morocco equally, the dismantling of migrant camps in the North was disguised in a humanitarian nature, and justified as both responding to fighting smuggling networks and of redirecting people to cities where integration might be easier (Benjelloun, 2017). These discourses depict destruction as a way to protect migrants from the risks of border crossing, and as such makes them more acceptable in the eyes of the public. This obviously obscures the fact that, beyond the violence to which migrants might be exposed during anti-smuggling operations, the latter potentially leave migrants without any form of shelter, without any alternative legal crossing pathway, and potentially stuck in countries like Libya.

\section{Slow control}

Compared to fast instruments of control, slow violence distinguishes itself by being less physical, less recognizable and, thus, less likely to meet resistance (Gazzotti, 2021). Slow methods of border control include protracted waiting to be regularized, granted asylum, or resettled, the exclusion from healthcare, education and work, and a structurally higher vulnerability to exploitation. These are forms of containment that are less legible, but no less assertive, than building fences (Gross-Wyrtzen, 2019) because they are based on a "discontinuous 'hold' over migrants' lives," made of some sites and moments in which migrants are highly controlled and others in which their movements are managed through (partial) non-governing, not-seeing and non-registration" (Aradau \& Tazzioli, 2019, p. 201).

As I mentioned earlier, anti-smuggling activities too can rely on methods that are much more mundane than military-like interventions, and on actors that lie beyond the security apparatus of the state. NGOs and IOs, in particular, have been coopted in the implementation of antismuggling activities based on welfare-like methods. These include information campaigns (Oeppen, 2016; Pécoud, 2010; Williams, 2019), and the re-deployment of former smugglers or "would-be" migrants into alternative business opportunities (Gazzotti, 2018; Howden \& Zandonini, 2018; Tazzioli, 2014). Information campaigns have become quite popular as an instrument deployed to curb people's willingness to rely on smugglers to cross the border irregularly. The campaigns thus try to dismantle "false myths" about smugglers; for example, they 
would spread false rumours about the journey conditions and the living opportunities in the destination countries to deceive "potential clients" into travelling (Oeppen, 2016). These campaigns are generally premised on the belief that, if given correct information about the "realities" of the journey, "would be migrants" would make better decisions about their potential journey. According to policy-makers, the "right" decision corresponds to refraining from migrating, or to migrating legally (even though legal migration avenues are only accessible for an extremely limited audience of people). Rather than disrupting smuggling through methods that destroy physical spaces, disperse communities, and physically constrain people, information campaigns operate in intimate, non-conventional security spaces. Information leaflets are attached to the walls of a community centre, or they are distributed at football matches (Andersson, 2014). In other cases, messages revealing "the real truths" about migration are included in speeches recited by religious leaders during services (Watkins, 2020), or screened before movies projected in openair, donor-funded mobile cinemas (Heller, 2014). These information campaigns thus try to disrupt smuggling by leveraging on the feelings of fear, compassion and empathy that migrants might have (Williams, 2019). In other words, they hope to unmake smuggling by shaping the subjectivity of 'potential' migrants, by influencing their capacity of decision-making, by transforming them into actors that think and move according to the logics of the border.

The provision of vocational training and alternative business opportunities to both "potential migrants" and former smugglers is another form of slow policing that aspires to disrupt the facilitation of irregular migration not through destruction, but by fulfilling the needs and aspirations through other means. Labour has always played a central role in border control strategies, and on development-based security interventions more broadly (Gazzotti, 2018). Since the early 2000s, donors, NGOs and IOs have on many occasions resorted to labour integration programmes to immobilise different categories of migrants, or 'potential' migrants. All these programmes were based on the (simplistic) belief that employment, often in the form of precarious jobs, could alone constitute an alternative to emigration (Rodriguez, 2015). Such projects have been recently trialled in Niger, where the approval of the 2015 Law Against Illicit Smuggling of Migrants, which criminalized the facilitation of irregular migration, disrupted the human smuggling business, which was deeply embedded in the local political economy of Agadez and the surrounding region. The imposition of tighter border control norms by Nigerien authorities, under the pressure of the EU, thus considerably increased unemployment levels in an area already marked by very high poverty rates (Comolli, 2019). The EU thus decided to implement the Action Plan for Rapid Economic Impact in Agadez (PAIERA) programme. Funded through the EU Trust Fund for Africa, the $€ 8$-million programme aimed at reconverting the former smuggling economy writ large - not only the people arranging the crossing and driving people through the desert, but also those providing services (namely "owners of hostels or brothels [maison close] that accommodate migrants," "the prostitution sector that developed alongside migrant smuggling," and "the business owner of legal activities that developed alongside smuggling”) (EU Commission, n.d.). According to an article published by Open Migration, around 6,000 former "migration players" in the Agadez region submitted applications for projects to be funded by the PAIERA programme, which granted up to 1500,000 CFA (around $€ 2,300$ ) to start new businesses (Zandonini, 2017). Like information campaigns, labour-based approaches to anti-smuggling also individualise the responsibility for disrupting irregular migration onto the single (former) smuggler, smuggler's client, or indirect beneficiary from the smuggling business. Building on a sedentary and colonial approach to human development and wellbeing (Bakewell, 2008; Landau, 2018), these projects thus try to shape the subjectivity of potential migrants, smugglers and their communities to produce law-abiding subjects who make a living through licit rather than illicit means (the latest including all migration or smuggling-related endeavours). 


\section{On the "unintended effects" of the military/humanitarian war against smugglers}

Whether anti-smuggling operations are actually effective in reducing smuggling is a source of debate. In Morocco, activists and journalists label destruction-and-dispersal policies as "nonsense." Migrants forcibly displaced to the Centre and South of the country, in fact, often go back to their places of residence within a few days (Gazzotti and Hagan, 2020). This specific anti-smuggling operation, therefore, does not seem "effective" because it does not achieve its stated intent - i.e., dismantling smuggling networks or keeping migrants away from the physical borders of the state. Similarly, both researchers and the International Organization for Migration (IOM) have raised doubts regarding the capacity of information campaigns to curb the propensity for irregular migration and the actual magnitude of existing migratory flows. Brachet found that information campaigns lacked cultural sensitivity, and paradoxically utilised symbols associated with health and prosperity, which induced more people to leave (Brachet, 2016). Hernandez-Carretero and Carling, instead, argue that information campaigns do not compound the fact that taking the risk to pursue dangerous border crossing activities might be considered socially acceptable in areas with high-emigration rates (Hernández-Carretero \& Carling, 2012). IOM researchers, instead, found that rigorous evidence on efficiency was scarce, and that information campaigns, in other words, had become widespread as a border control tool in spite of any consideration about whether they actually worked or not (IOM GMDAC, 2018). Similar critiques exist for the PAIERA programme (Howden \& Zandonini, 2018): local stakeholders claim that the economic packages provided by the programme are too meagre to facilitate the creation of alternative jobs for the over 5000 former smugglers living in the region. In the field of migration control, anti-smuggling policies are not the only ones to be implemented despite not being effective even on their own terms: Ruben Andersson brands the entire border economy as absurd, because it keeps on expanding and reproducing itself even though irregular migration continues unabated (Andersson, 2014).

Although anti-smuggling activities might not be effective in curbing smuggling and irregular migration tout-court, this does not mean that they do not do anything. Much to the contrary, these activities expand control over the mobility of people moving from marginalized communities in the South to the North in ways that are not captured in project factsheets or in journalistic prose. In Morocco, for example, dispersal policies aiming at dismantling smuggling networks activate multiple mechanisms of dispossession that keep migrants both far away from the border and at the margins of Moroccan society. Although many migrants manage to go back to their places of residence, many others remain stuck in the areas where they have been abandoned due to lack of funding to buy return tickets or to the refusal of public transport companies to carry people profiled as irregular migrants. The destruction of one's belongings and the forcible displacement to other areas, where employment opportunities are scarce or the working conditions are exploitative, prevent people from really settling and enjoying the economic and personal security needed to have a decent life. Many migrants get stuck in a state of hyper-mobility, in a cycle of mobility and forced displacement that leads them to wander from city to city, in an unbearable state of living (Gazzotti \& Hagan, 2020).

Similarly, information campaigns or labour programmes aiming at converting the smuggling economy into a licit market might not reduce the structural causes creating the need for the facilitation of irregular border crossing in the first place. However, they do create the feeling that smuggling can be managed through a set of light-touch, technical instruments that do not put into question the status quo, including the existence of restrictive migration policies, the stark inequalities and economic precarity affecting border areas, and the existence of a tradition 
of migration in areas of origin and transit. Although military and humanitarian responses to human smuggling might appear neatly distinct, they both consolidate restrictive migration policies: they displace attention away from the structural causes that produce irregular migration, smuggling, and border violence in the first place; they pathologise smuggling and irregular migration as 'deviances' that need to be prosecuted; and they legitimise security-based interventions aimed at containing people deemed dangerous to the security of countries in the Global North.

\section{Conclusion}

The ramping up of border surveillance policies around the world has transformed human smuggling into the target of both hard and soft security interventions. In this landscape, the figure of the "smugglers" has become demonized as a source of threat for both migrants (who are deceived into and abused during dangerous border crossings) and destination countries (whose borders and integrity are supposedly violated by irregular migrants and their facilitators). Academic literature has widely discarded the idea of "smugglers" as inherently dangerous and deviant figures. Scholars have highlighted that a more accurate understanding of "smuggling" should read this activity within the situated moral and political economy of borders. Depending on the context, the relationship between smugglers and their "clients" can thus lie on a variegated spectrum ranging from overt violence to trust and care. Furthermore, smuggling can be a mundane activity that is deeply embedded in the local economy of border regions. Nevertheless, this biased representation has remained commonplace in policy discourses, to the point of being upheld as a justification for militarized border interventions.

In this chapter, I have argued that casting attention on the "dangerous smuggler" as a societal enemy (which endangers both migrant people and the population in countries of destination) is strategical. By obscuring the complex, political causes of irregular border crossing, demonizing smugglers allows policy-makers to tighten the objective of border intervention to a series of time-bound, space-bound, manageable interventions. This process of strategy reduction and technicalisation thus facilitates the reproduction of the migration control apparatus, which expands into a number of heterogenous interventions aimed at disrupting the business model of smugglers. Building on the work of Rob Nixon, I argued that anti-smuggling operations could be divided into fast and slow policing instruments. Fast methods of smuggling policing rely on military-style interventions, implemented by actors close to the traditional circuits of state security. They aim at disrupting smuggling through destruction - of migrants' gatherings, of the spaces where migrants wait, of the infrastructures used to cross. The violence that characterize these interventions is deeply physical - it acts through the destruction and annihilation of things, spaces, and people themselves. Slow instruments of anti-smuggling rely on a radically different from of intervention, that takes the form of welfare-like initiatives promoted by actors that lie outside the traditional circuits of state security. Rather than focusing on the physical destruction of smuggling infrastructures, slow anti-smuggling interventions utilize a productive approach to border control, which is less physical in nature as it does not operate at the level of the body or of the physical space, but rather aims at shaping the subjectivities of both potential migrants, former smugglers, and the communities revolving around the smuggling business.

\section{Notes}

1 I paraphrase here the title of James Ferguson's piece on the "uses" of neoliberalism (Ferguson, 2010).

2 Whilst seemingly paradoxical, the combination of such different types of intervention has become 
commonplace in contemporary conflicts. In a 2003 article, Michel Agier explained the symbiosis between humanitarian and militarized intervention as "the left and right hand of the empire." Building on Bourdieu, Agier argues that the humanitarian apparatus (the left hand) is left to mend the damages created by armed operations (the right hand) - in a sinister symbiosis where "one hand [...] strikes, the other one [...] heals" (Agier 2003: 67). However, conceptualizing the military-humanitarian security apparatus in terms of a left and right hand risks to understate the explicit (rather than collateral) control functions performed by "softer" interventions.

3 Other scholars have named this form of chronic dispossession as "abandonment," or a technique of governance premised on the "state's selective presence and absence in community members' lives" (Denyer Willis, 2018, p. 333), which operates through "exhaustion, destitution, continual surveillance, paternalist policies, and formal and informal incarceration" (Gross-Wyrtzen, 2020: 8).

\section{References}

Achilli, L. (2018). The "Good" Smuggler: The Ethics and Morals of Human Smuggling among Syrians. The ANNALS of the American Academy of Political and Social Science, 676(1), 77-96. https://doi.org/ $10.1177 / 0002716217746641$

Andersson, R. (2014). Illegality, Inc.: Clandestine Migration and the Business of Bordering Europe (1st edition). University of California Press.

Aradau, C., \& Tazzioli, M. (2019). Biopolitics Multiple: Migration, Extraction, Subtraction. Millennium, 48(2), 198-220. https://doi.org/10.1177/0305829819889139

Bajalia, A. G. (2020). Dima Africa, Daily Darija: Im/migrant Sociality, Settlement, and State Policy in Tangier, Morocco. The Journal of North African Studies, 1-20. https://doi.org/10.1080/13629387.2020. 1800212.

Bakewell, O. (2008). 'Keeping Them in Their Place': The Ambivalent Relationship Between Development and Migration in Africa. Third World Quarterly, 29(7), 1341-1358.

Baldwin-Edwards, M., Blitz, B. K., \& Crawley, H. (2019). The Politics of Evidence-based Policy in Europe's 'migration Crisis.' Journal of Ethnic and Migration Studies, 45(12), 2139-2155. https://doi.org/ 10.1080/1369183X.2018.1468307

Ben Jémia, M. (2012). La Tunisie, cerbère des frontières européennes. Plein droit, 73, 35-38.

Benjelloun, S. (2017). Nouvelle politique migratoire et opérations de régularisation. In M. Alioua \& J.-N. Ferrié (Eds.), La nouvelle politique migratoire marocaine (pp. 35-76). Konrad Adenauer Stiftung.

Brachet, J. (2016). Policing the Desert: The IOM in Libya Beyond War and Peace. Antipode, 48(2), 272-292. https://doi.org/10.1111/anti.12176

Carling, J., \& Hernández-Carretero, M. (2011). Protecting Europe and Protecting Migrants? Strategies for Managing Unauthorised Migration from Africa. The British Journal of Politics and International Relations, 13, 42-58. https://doi.org/10.1111/j.1467-856x.2010.00438.x

Comolli, V. (2019). Niger: Curtailing Migration has Unintended Consequences, International Institute for Strategic Studies. https://www.iiss.org/blogs/analysis/2019/11/csdp-curtailing-migration-niger

De Genova, N. (2010). Antiterrorism, Race, and the New Frontier: American Exceptionalism, Imperial Multiculturalism, and the Global Security State. Identities, 17(6), 613-640. https://doi.org/10.1080/ 1070289X.2010.533523

De Noronha, L. (2020). Deporting black Britons: Portraits of deportation to Jamaica / Luke de Noronha. Manchester University Press, 2020.

Denyer Willis, L. (2018). "It Smells Like a Thousand Angels Marching": The Salvific Sensorium in Rio de Janeiro's Western Subúrbios. Cultural Anthropology, 33(2), 324-348. https://doi.org/10.14506/ ca33.2.10

European Commission. (n.d.). Migrant Smuggling. https://ec.europa.eu/home-affairs/what-we-do/ policies/irregular-migration-return-policy/facilitation-irregular-migration_en

Ferguson, J. (1994). The Anti-Politics Machine: Development, Depoliticization, and Bureaucratic Power in Lesotho (New edition). University of Minnesota Press.

Ferguson, J. (2010). The Uses of Neoliberalism. Antipode, 41, 166-184. https://doi.org/10.1111/j.14678330.2009.00721.x

Garelli, G., \& Tazzioli, M. (2018). The Humanitarian War Against Migrant Smugglers at Sea. Antipode, 50(3), 685-703. https://doi.org/10.1111/anti.12375 
Gazzotti, L. (2021). Immigration Nation. Aid, Slow Control, and Border Politics in Morocco. Cambridge University Press.

Gazzotti, L. (2018). From Irregular Migration to Radicalisation? Fragile Borders, Securitised Development and the Government of Moroccan Youth. Journal of Ethnic and Migration Studies, 45(1), 1-22.

Gazzotti, L., \& Hagan, M. (2020). Dispersal and Dispossession as Bordering: Exploring Governance Through Mobility in Post-2013 Morocco. Journal of North African Studies. https://doi.org/10.1080/ 13629387.2020.1800209.

Gross-Wyrtzen, L. (2019). Bordering Blackness: The Production of Race in the Morocco-EU Immigration Regime. PhD thesis, Clark University.

Gross-Wyrtzen, L. (2020). Policing the Virus: Race, Risk, and the Politics of Containment in Morocco and the United States." Roundtable on Borders and the State in Light of COVID-19. Security in Context. https://www.securityincontext.com/publications/borders-roundtable-policing-the-virus

Hagan, M. (2020). The Contingent Camp: Struggling for Shelter in Calais, France. In T. Scott-Smith \& M. Breeze (Eds.), Structures of Protection? Rethinking Refugee Shelter. Berghahn Books.

Heller, C. (2014). Perception Management - Deterring Potential Migrants Through Information Campaigns. Global Media and Communication, 10(3), 303-318. https://doi.org/10.1177/1742 766514552355

Hernández-Carretero, M., \& Carling, J. (2012). Beyond "Kamikaze Migrants": Risk Taking in West African Boat Migration to Europe. Human Organization, 71(4), 407-416. https://doi.org/10.17730/ humo.71.4.n52709742v2637t1

Hollande, F. (2016). Déclaration de M. François Hollande, Président de la République, sur l'action des forces de sécurité et le démantèlement du campement de migrants, à Calais le 26 septembre 2016. https://www.viepublique.fr/discours/200512-declaration-de-m-francois-hollande-president-de-la-republique-sur-la

Howden, D., \& Zandonini, G. (2018). Niger: Europe's Migration Laboratory. Refugees Deeply. https:// www.newsdeeply.com/refugees/articles/2018/05/22/niger-europes-migration-laboratory

IOM. (n.d.). IOM's comprehensive approach to counter migrant smuggling. https://www.iom.int/sites/default/ files/our_work/DMM/IBM/IOM-Approach-to-counter-migrant-smuggling-Brochure.pdf

IOM GMDAC. (2018). Evaluating the impact of information campaigns in the field of migration: A systematic review of the evidence, and practical guidance. https://gmdac.iom.int/sites/default/files/papers/evaluating the_impact_of_information_campaigns_in_field_of_migration_iom_gmdac.pdf

Khrouz, N. (2016). La pratique du droit des étrangers au Maroc. Essai de praxéologie juridique et politique. PhD thesis, unpublished. Université Grenoble Alpes.

Landau, L. B. (2018). A Chronotope of Containment Development: Europe's Migrant Crisis and Africa's Reterritorialisation. Antipode, 15(7). https://doi.org/10.1111/anti.12420

Magallanes-Gonzalez, C. (2020). Sub-Saharan Leaders in Morocco's Migration Industry: Activism, Integration, and Smuggling. Journal of North African Studies. https://doi.org/10.1080/13629387.2020. 1800213.

Nixon, R. (2011). Slow Violence and the Environmentalism of the Poor. Harvard University Press.

Oeppen, C. (2016). 'Leaving Afghanistan! Are you sure?' European efforts to deter potential migrants through information campaigns. Human Geography, 9(2), 57-68.

OXFAM. (2018). Nulle part où aller. L'échec de la France et de l'Italie pour aider les réfugié-e-s et autres migrant-e-s échoué-e-s à la frontière vers Vintimille.

Pécoud, A. (2010). Informing Migrants to Manage Migration? An Analysis of IOM's Information Campaigns. In The Politics of International Migration Management (pp. 184-201). Palgrave Macmillan.

Rodriguez, A.-L. (2015). Three Stories About Living Without Migration in Dakar: Coming to Terms With The Contradictions of the Moral Economy. Africa, 85(2), 333-355. https://doi.org/10.1017/ S0001972015000042

Sanchez, G. (2016). Women's Participation in the Facilitation of Human Smuggling: The Case of the US Southwest. Geopolitics, 21(2), 387-406. https://doi.org/10.1080/14650045.2016.1140645

Slack, J. (2019). Deported to Death: How Drug Violence Is Changing Migration on the US-Mexico Border/Jeremy Slack. University of California Press.

Stock, I. (2019). Time, Migration and Forced Immobility: Sub-Saharan African Migrants in Morocco/Inka Stock. Bristol University Press.

Tazzioli, M. (2014). Spaces of Governmentality: Autonomous Migration and the Arab Uprisings. Rowman \& Littlefield International.

Tazzioli, M. (2019). The Politics of Migrant Dispersal. Dividing and Policing Migrant Multiplicities. Migration Studies, mnz003. https://doi.org/10.1093/migration/mnz003. 
Tyszler, E. (2019). Derrière les barrières de Ceuta \& Melilla. Rapports sociaux de sexe, de race et colonialité du contrôle migratoire à la frontière maroco-espagnole. $\mathrm{PhD}$ thesis, Université Paris 8 , unpublished.

UNODC. (n.d.). Migrant Smuggling FAQs. https://www.unodc.org/unodc/en/human-trafficking/ migrant-smuggling/faqs.html\#m6

Vives, L. (2017). The European Union-West African Sea Border: Anti-immigration Strategies and Territoriality. European Urban and Regional Studies, 24(2), 209-224. https://doi.org/10.1177/ 0969776416631790

Vogt, W. (2016). Stuck in the Middle With You: The Intimate Labours of Mobility and Smuggling along Mexico's Migrant Route. Geopolitics, 21(2), 366-386. https://doi.org/10.1080/14650045.2015. 1104666

Watkins, J. (2017). Bordering Borderscapes: Australia's Use of Humanitarian Aid and Border Security Support to Immobilise Asylum Seekers. Geopolitics, 22(4), 958-983. https://doi.org/10.1080/14650045. 2017.1312350

Watkins, J. (2020). Irregular Migration, Borders, and the Moral Geographies of Migration Management. Environment and Planning C: Politics and Space, 2399654420915607. https://doi.org/10.1177/ 2399654420915607.

Williams, J. (2019). Affecting Migration: Public Information Campaigns and the Intimate Spatialities of Border Enforcement. Environment and Planning C: Politics and Space, 2399654419833384. https:// doi.org/10.1177/2399654419833384

Zandonini, G. (2017). "I'm Not a Criminal": The Story of a Former Passeur in Niger. OpenMigration. https://openmigration.org/en/analyses/im-not-a-criminal-the-story-of-a-former-passeur-in-niger/ 